\title{
Biogeochemistry and ecology of Pyrosoma spinosum from the Central Arabian Sea
}

\author{
Mangesh Gauns, Sunita Mochemadkar, Anil Pratihary, Rajdeep Roy and Syed Wajih Ahmad Naqvi
}

\begin{abstract}
Background: A swarm of pelagic tunicate (Pyrosoma spinosum) was found in the surface open waters of the Arabian Sea during late southwest monsoon (September 2007). The swarm site was characterized by moderate southwesterly wind (approximately $7 \mathrm{~m} \mathrm{~s}^{-1}$ ), relatively low sea-surface temperature (approximately $26^{\circ} \mathrm{C}$ ), shallow mixed layer (approximately $50 \mathrm{~m}$ ), and substantial macro-nutrient concentrations (surface values: $2.5 \mu \mathrm{M}$ nitrate, $0.3 \mu \mathrm{M}$ phosphate, $0.9 \mu \mathrm{M}$ silicate, and $5.0 \mu \mathrm{M}$ ammonium). Despite adequate macronutrient availability, the swarm site was characterized by low diversity of phytoplankton $(>5 \mu \mathrm{m})$ and mesozooplankton in the upper $200 \mathrm{~m}$. Low chlorophyll a concentration $\left(27.3 \mathrm{mg} / \mathrm{m}^{2}\right.$ in the upper $120 \mathrm{~m}$ ) at the swarm site was dominated (90\% to $95 \%$ in the upper $40 \mathrm{~m})$ by the Synechococcus $\left(20 \times 10^{6} / \mathrm{ml}\right)$.
\end{abstract}

Results: Silicate deficiency in surface waters upwelled or entrained from the thermocline may be a key factor for the dominance of smaller autotrophs (flagellates and cyanobacteria) that seems to offer favorable conditions for episodic occurrence of swarms of these filter feeders. Low carbon content (37\% of total dry weight) and the lower molar (carbon-to-nitrogen) ratio (5) in P. spinosum suggest growth of these organisms is carbon-limited.

Conclusions: We describe various physicochemical and biological conditions at the P. spinosum swarm location and at two other nearby sites not affected by it. The biological factors predominantly high densities of Synechococcus and flagellates were best suited conditions for the proliferation of pyrosome biomass in the central Arabian Sea.

Keywords: Pyrosoma spinosum; Arabian Sea; Biogeochemistry; Phytoplankton; Zooplankton

\section{Background}

Pyrosoma is a genus of warm-water protochordates consisting of a large number of small individual organisms (called zooids), which remain together in the form of a drifting colony. These colonies range in size from microscopic to $>10 \mathrm{~m}$ long (Griffin and Yaldwyn 1970). Interestingly, each zooid of the colony remains independent of others. Each zooid feeds by passing a current, containing particles and organisms, through a mucuscovered branchial basket that retains particles including bacteria. Picophytoplanktons, which contribute significantly to the global primary production, are abundantly found in the Arabian Sea even during the southwest monsoon period (Brown et al. 1999). Analysis of gut contents of Pyrosoma (Hart, as cited by Culkin and Morris 1970) showed that the main food $(80 \%)$ was phytoplankton belonging to the classes Haptophyceae, Chrysophyceae, and

\footnotetext{
* Correspondence: gmangesh@nio.org

National Institute of Oceanography (Council of Scientific and Industrial Research), Dona Paula, Goa 403004, India
}

Bacillariophyceae. The remainder was composed of protozoan species such as radiolarians and tintinnids.

Geographically, pyrosome forms are found distributed worldwide, commonly in the warm tropical and temperate waters, particularly between $50^{\circ} \mathrm{N}$ and $50^{\circ} \mathrm{S}$ (Sewell 1953, Van Soest 1981) but not in polar waters. In the water column, they occur at the surface as well as in the dark region of the deep sea. They have been collected from depths well in excess of 3,000 m (Millar 1971).

The trophodynamic role of other pelagic tunicates such as salps, doliolids, and appendicularians in the pelagic ecosystem is known to some extent (see Harbison and Gilmer 1976, Wiebe et al. 1979, Alldredge 1981, Deibel 1982, 1986, 1988, Madin 1982, Madin and Cetta 1984, Naqvi et al. 2002). In comparison, much less is known about pyrosomes even though early work on these tunicates dates back to early nineteenth century (Peron 1804). The pyrosomes as pelagic zooplankton are of special interest in the trophodynamics of planktonic ecosystems as they occasionally rival crustaceans as the dominant planktonic 
herbivores (Thompson 1948, Bary 1960). The presence of these forms considerably increases the standing crop of secondary producers (Angel 1989). That study also points out that pyrosomes undertake extensive vertical migration going down to 500 to $700 \mathrm{~m}$ or even deeper during the day and ascending into the mixed layer at night. The vertical movement of these organisms highlights the importance of biological factors influencing the fluxes of material (Roe et al. 1987), similar to myctophids (Morrison et al. 1999) and copepods (Wishner et al. 2008, Takahashi et al. 2009).

The only mention of $P$. spinosum (apart from $P$. verticillatum, $P$. aberniosum, and $P$. atlanticum) comes from the southern part of the Arabian Sea (off the Arabian coast and in the Gulf of Aden) during the John Murray Expedition (1933 to 1934) (Sewell 1953) and from the work of Neumann (1913) from the equatorial zone $\left(8^{\circ} \mathrm{N}\right.$ to $\left.10^{\circ} \mathrm{S}\right)$. During the IIOE (1960 to 1965), pyrosomes were found restricted to the south of $10^{\circ} \mathrm{N}$ (see Indian Ocean Biological Centre 1973). However, occurrence of massive pyrosome colonies is at least not known in the northern Arabian Sea. This article records their occurrence in the region based on observations made in the summer of 2007. The possible reason and significance are examined in the present study.

\section{Methods}

The climate and oceanographic processes of the Arabian Sea, our study area, is very different from the other ocean basins as a result of its uncommon geographical setting. This region experiences seasonally reversing monsoon winds. The winds blow from the northeast in winter (November to February; northeast monsoon) and from the southwest in summer (June to September; southwest monsoon). The southwest monsoon is the most important period for the region because the strong southwesterly wind forces vigorous upwelling off Somalia, Yemen, and Oman in the western Arabian Sea are resulting in large-scale nutrient enrichment of the euphotic zone that extends about $1,000 \mathrm{~km}$ offshore. The present study was carried out to the end of the southwest monsoon in 2007.

\section{Sampling}

During the middle of the day, a pyrosome swarm was observed during a cruise of R/V Roger Revelle cruise at station 20 (lat. $15^{\circ} 58^{\prime} \mathrm{N}$; long. $62^{\circ} 00^{\prime} \mathrm{E}$; Figure 1 ) on 10 September 2007. The pyrosome colonies appeared to be long, pinkish-red colored, worm-like floating objects due to water motion. Specimens were collected without causing much damage with a large capacity $(20 \mathrm{~L})$ widemouth plastic bucket. The longest colony was roughly $0.8 \mathrm{~m}$ long and $16 \mathrm{~cm}$ wide; since it was cut and open on one side, the actual length must have been even longer. A much longer colony (approximately $2 \mathrm{~m}$ ) was recovered at night entangled to the CTD rosette (cast to

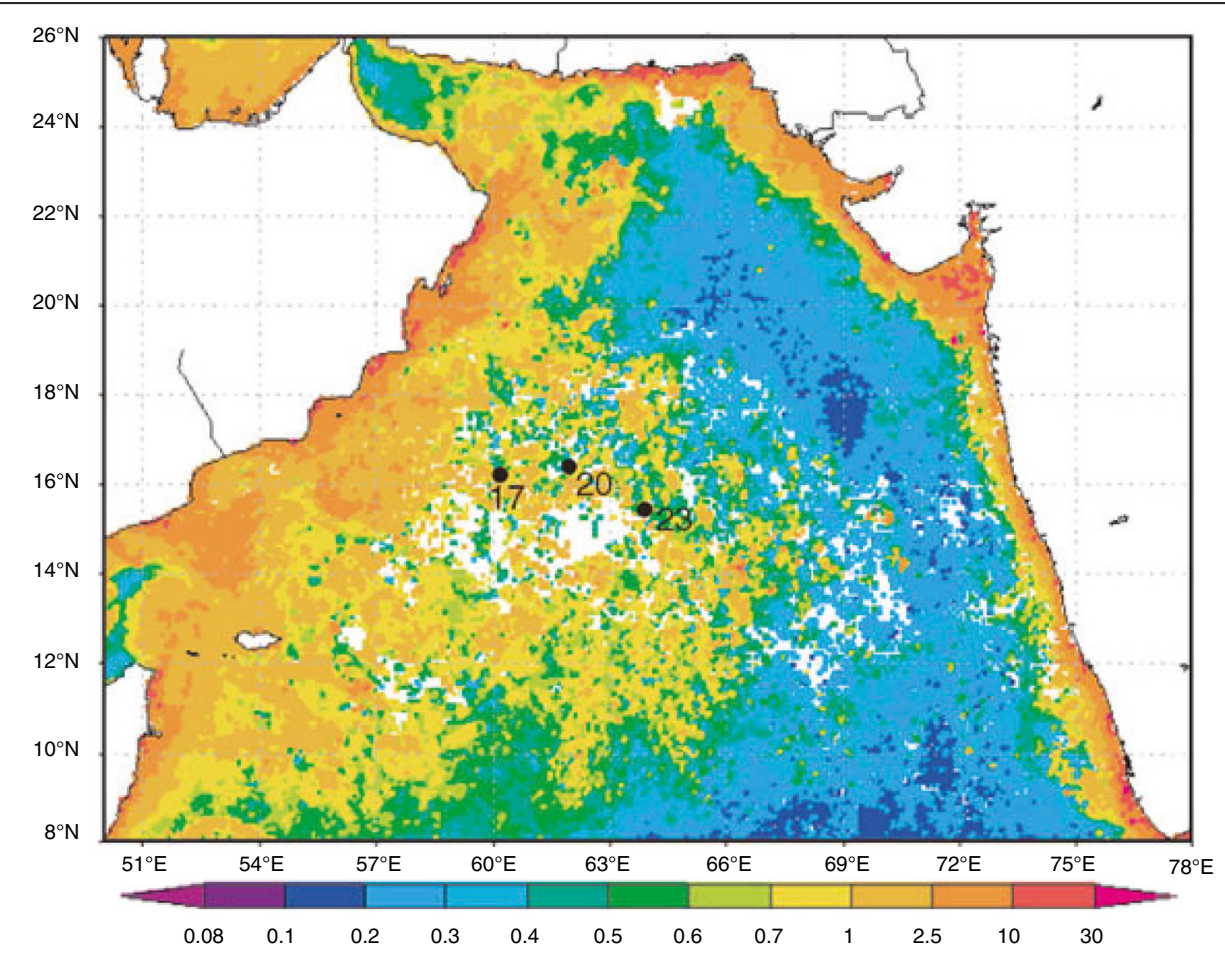

Figure 1 Map showing SeaWiFS Chl $\boldsymbol{a}$ image. For August to September 2007 (source:http://gdata1.sci.gsfc.nasa.gov/daac-bin/G3/gui.cgi? instance_id=ocean_month) with superimposed station locations [station 20: pyrosome swarm station; stations 17and 23: stations for comparison]. 
$120 \mathrm{~m}$; see Additional file 1). Tubular colonies were cut open to measure the length and width.

To explore the ecological and biogeochemical significance of pyrosome swarm, we collected physicochemical and biological data from the swarm station as well as from two other nearby stations that were occupied on 9 September 2007 (station 17: lat. $15^{\circ} 47.77^{\prime} \mathrm{N}$, long. $60^{\circ}$ $15.02^{\prime} \mathrm{E}$ ) and on 12 September 2007 (station 23: lat. $15^{\circ}$ $00^{\prime} \mathrm{N}$, long. $63^{\circ} 59^{\prime} \mathrm{E}$ ). All three stations were sampled during the day. Water samples were collected and processed as per JGOFS Protocols (UNESCO 1994). Temperature and salinity profiles were obtained from a conductivity-temperature-depth (CTD) unit (Sea Bird Electronics, Bellevue, WA, USA) mounted on a rosette having 24, 12-liter Go-FLO bottles (General Oceanics, Miami, FL, USA) for water sampling. Water samples were collected from different depths in the upper $120 \mathrm{~m}$ for chemical measurements and for estimating phytoplankton composition and standing stock (total- and size-based chlorophyll $a$ ), enumeration of heterotrophic nanoflagellates and bacteria. Mesozooplankton samples were collected from five strata (based on the physical structure of the water column) using a Multiple Plankton Net $(200 \mu \mathrm{m}$; HYDRO-BIOS, Kiel-Holtenau, Germany) from the upper $1,000 \mathrm{~m}$. Details of sampling and processing procedures are as follows.

\section{Chemical measurements}

Chemical analyses of water samples for dissolved oxygen and nutrients were performed following standard procedures (SCOR 1996). Dissolved oxygen was analyzed following the Winkler titrimetric procedure using an automated system built and supplied by the Scripps Institution of Oceanography/Ocean Data Facility (SIO/ODF) group. Nutrients were measured with a SKALAR Analyzer (SKALAR, Breda, the Netherlands).

A portion of the colony was frozen at $-80^{\circ} \mathrm{C}$, and the remainder was then preserved separately in ethanol (70\%) and hexamine-buffered formaldehyde (4\%). Small portions of the colony $(3 \times 3 \mathrm{~cm}$, approximately 60 zooids) were thoroughly washed in milli-Q water (Millipore Corporation, Darmstadt, Germany) and dried at $60^{\circ} \mathrm{C}$ for measurements of C-to- $\mathrm{N}$ ratio and stable isotopic $\left(\delta^{13} \mathrm{C}\right.$ and $\delta^{15} \mathrm{~N}$ ) composition by an isotopic ratio mass spectrophotometer coupled to an elemental analyzer. Isotopic ratios were measured relative to Peedee Belemnite for carbon and atmospheric $\mathrm{N}_{2}$ for nitrogen. Precision values of $0.2 \%$ for $\delta^{13} \mathrm{C}$ and $0.3 \%$ for $\delta^{15} \mathrm{~N}$ were obtained by multiple measurements of an external standard. Protein content of the organism extracted using the method of Rausch (1981) was quantified following Bradford (1976). For this purpose, two randomly picked pieces of the Pyrosoma colony $(3 \times 3 \mathrm{~cm})$ were freeze-dried before extraction in $5 \mathrm{ml}$ of buffer (in triplicate). Absorbance was measured at $595 \mathrm{~nm}$.

\section{Biological measurements Phytoplankton biomass (chlorophyll a)}

Duplicate samples $(1 \mathrm{~L})$ from each depth $(0,10,20,40$, $60,80,100$, and $120 \mathrm{~m}$ ) were filtered through $47-\mathrm{mm}$ GF/F filters $(0.7 \mu \mathrm{m}$ pore size). Chlorophyll $a(\mathrm{Chl} a)$ was extracted in $10 \mathrm{ml}$ of $90 \%$ acetone in the dark for $24 \mathrm{~h}$ at $4^{\circ} \mathrm{C}$. A fluorometer (Turner Designs, Sunnyvale, CA, USA) was used for measuring fluorescence.

\section{Size-fractionated phytoplankton biomass}

A known volume of water sample (2 to $5 \mathrm{~L}$ ) was passed serially through different pore size filters $(200,60,20$, and $10 \mu \mathrm{m}$ nylon and $0.7 \mu \mathrm{m}$ GF/F). These filters were then processed following the procedure described above for total Chl $a$.

\section{Phytoplankton cell counts $(>10 \mu \mathrm{m})$}

A sub-sample of $250 \mathrm{ml}$ from each of the above mentioned eight depths was fixed in $2 \%$ Lugol's iodine and preserved by adding $3 \%$ formaldehyde. All samples were stored in the dark at room temperature until enumeration. A settling and siphoning procedure was followed to concentrate the samples. Two replicates of $1 \mathrm{~mL}$ of the concentrated samples were then examined microscopically in a Sedgewick-Rafter plankton counting chamber (Structure Probe, Inc., West Chester, PA, USA) at $\times 200$ magnification.

\section{Flow cytometry}

Abundances of Synechococcus and picoeukaryotes were determined in glutaraldehyde (1\% final concentration) fixed samples. All samples were frozen instantly in liquid nitrogen. Population was identified on FACSCalibur (Becton-Dickinson Biosciences, Franklin Lakes, NJ, USA) flow cytometer according to population fluorescence and light scatter characteristics (Vaulot et al. 1990).

\section{HPLC pigments}

Water samples (2 to $3 \mathrm{~L}$ ) for pigment analyses were filtered through GF/F $(0.7 \mu \mathrm{m}, 25 \mathrm{~mm}$ diameter $)$ and the filters stored at $-85^{\circ} \mathrm{C}$ until analysis in the shore laboratory a few weeks after the cruise. Phytoplankton pigments from the frozen filters were extracted in $3 \mathrm{ml} \mathrm{95 \%}$ acetone $(v / v$ in deionized water) in $5 \mathrm{~min}$, using an ultrasonic bath $(5 \mathrm{~s}, 20 \mathrm{kHz})$ filled with ice water. These extracts were then stored overnight at $-20^{\circ} \mathrm{C}$ for high performance liquid chromatography (HPLC) analysis. Samples were later passed through a Teflon syringe cartridge (Millipore) (pore size $0.45 \mu \mathrm{m}$, diameter $25 \mathrm{~mm}$ ) to remove the cellular debris. The clear extract was collected in a 2-ml glass vial and placed directly into the 
temperature-controlled $\left(5^{\circ} \mathrm{C}\right)$ auto-sampler tray for HPLC analysis. The entire extraction procedure was carried out in dim light conditions and at low temperature to minimize degradation of pigments. The HPLC analysis was carried out following the method of Van Heukelem (2002) as detailed in Roy et al. (2006); however, the buffer used in this case was Tetrabutylammonium Acetate which had a concentration of $0.025 \mathrm{M}$. In the present study, the sum of 19-hexanoyloxyfucoxanthin (19'HF), 19-butanoyloxyfucoxanthin (19BF), alloxanthin (Allo), and chlorophyll $b$ was used to indicate nanoflagellate abundance. Zeaxanthin (Zea), fucoxanthin (Fuc), and peridinin (Per) were considered to represent cyanobacteria, diatoms, and dinoflagellates, respectively. Diagnostic pigment (DP) indices were calculated following the method of Barlow et al. (2007) for assessing the phytoplankton communities. Four major groups were evaluated. The indices representing the groups were designated as Diat $_{\text {DP }}$ (diatoms), Dino ${ }_{\text {DP }}$ (dinoflagellates), Flag DP $_{\text {(nano- }}$ flagellates), and Prok $\mathrm{DP}_{\text {(Prokaryotes). }}$

\section{Bacterial abundance}

Sub-samples $(20$ to $50 \mathrm{ml}$ ) from each of the depths mentioned above and additionally from 150, 200, 300, 500, 600 , and $800 \mathrm{~m}$ were fixed with $4 \%$ of $0.22-\mu \mathrm{m}$-filtered formaldehyde and stored at $4^{\circ} \mathrm{C}$ until DAPI stained direct counts (AODC) were made. Counting was done using an Olympus $\mathrm{BH} 2$ epifluorescence microscope (Olympus Corp., Tokyo, Japan).

\section{Heterotrophic nanoflagellates}

In order to determine the abundance of heterotrophic nanoflagellates, $100 \mathrm{ml}$ of each water sample was fixed in glutaraldehyde ( $2 \%$ final concentration). A known volume of water was filtered through $0.8 \mu \mathrm{m}$ black Nuclepore (Nuclepore, NJ, USA) filters (Booth 1993) after staining with DAPI and proflavine at the final concentration of $5 \mu \mathrm{g} / \mathrm{ml}$ and allowing staining for $5 \mathrm{~min}$ (Hass 1982, Booth 1993). Slides were prepared and held at $5^{\circ} \mathrm{C}$ in a darkened box until used for epifluorescence microscopy.

\section{Mesozooplankton biomass (ZP)}

The biomass of mesozooplankton was estimated as displacement volume after blotting it on an absorbent paper and then measuring in a graduated cylinder. This was done before preservation of the sample. In the shore laboratory, organisms were identified to the genus (species level in some forms) level under a stereo zoom microscope (magnification $\times 160$; Nikon Corp., Tokyo, Japan).

\section{Results}

\section{Physico-chemical parameters}

The P. spinosum swarm was found at station 20 . This region (study location) experienced relatively weaker southwesterly winds (3.3 to $9.9 \mathrm{~m} \mathrm{~s}^{-1}$; average $6.8 \pm 1.5$ ). Similarly, variations in air temperature were well within $1^{\circ} \mathrm{C}$ ( 25.5 to 26.1 ; average $25.8 \pm 0.15^{\circ} \mathrm{C}$ ). Sea surface temperature (SST) at station 17 (located to the southwest of study location; Figure 1) was $0.5^{\circ} \mathrm{C}$ cooler than the other two stations (20 and 23) indicating a greater influence of upwelled water advecting offshore from the coastal upwelling sites. At the latter two stations, both temperature and salinity were also low (Figure 2A, B). The mixed layer depth (MLD, inferred from the temperature profiles) was shallower at stations 20 and 17 (approximately $50 \mathrm{~m}$ ) than at station 23 (approximately $70 \mathrm{~m}$; Figure $2 \mathrm{~A}$ ). However, despite the deeper MLD and more offshore location of station 23, surface nitrate concentration at this station was slightly higher (approximately $4 \mu \mathrm{M}$ ) than at station 20 (approximately $2.5 \mu \mathrm{M}$ ). Station 17 had much higher surface nitrate, approximately $11 \mu \mathrm{M}$. A similar trend was observed with phosphate (Figure 3B) and silicate (Figure 3C), but ammonium was significantly higher (two- to sixfold) at station 20 (approximately $5 \mu \mathrm{M}$ ) than at other two stations. Dissolved oxygen concentrations (Figure 4) were $<0.5 \mathrm{ml} / \mathrm{L}$ between 200 and $1,000 \mathrm{~m}$ (except at $250 \mathrm{~m}$ ) at station 20. Even lower concentrations (close to or below the detection limit between 150 and $500 \mathrm{~m}$ ) were recorded at station 23 .

\section{Biological parameters \\ Chlorophyll a (total and size fractionated; fluorometric analysis)}

Contrary to expectations, availability of substantial macronutrients in surface waters at all three stations did not result in commensurately high $\mathrm{Chl}$ concentrations. This is consistent with the results of Naqvi et al. (2010) who proposed that phytoplankton productivity in this region is limited by iron toward the end of the southwest monsoon. However, despite the lowest macronutrient levels in surface waters among the three stations, the phytoplankton biomass was the highest at station 20, for both the surface Chl $a$ concentration $\left(0.60 \mathrm{mg} / \mathrm{m}^{3}\right)$ and the column inventory $\left(27.3 \mathrm{mg} / \mathrm{m}^{2} ; 0\right.$ to $\left.120 \mathrm{~m}\right)$. The total biomass (equivalent to station 17 ) was roughly $11.55 \mathrm{mg} / \mathrm{m}^{2}$ higher than at station 23 (Figure 5A). Further, analysis of phytoplankton biomass in different size fractions, carried out by gravity filtration, showed higher biomass in the larger $(>20 \mu \mathrm{m})$ fractions (approximately $48 \%$, Figure $5 \mathrm{~B}$ ) at stations 17 and 23 than at station 20 , where the biomass were largely dominated by the smaller $(<20 \mu \mathrm{m})$ fractions, (approximately $79 \%$; Figure $5 \mathrm{~B}$ ) indicating the dominance of pico- and nanoautotrophs. Further, the lower phaeopigment-to-chlorophyll ratio in the upper $60 \mathrm{~m}$ was significantly lower $(0.3 \pm 0.18)$ at station 20 than at the other two stations $(0.5 \pm 0.3)$ indicating relatively healthy autotrophic cells prevailing at station 20 . 

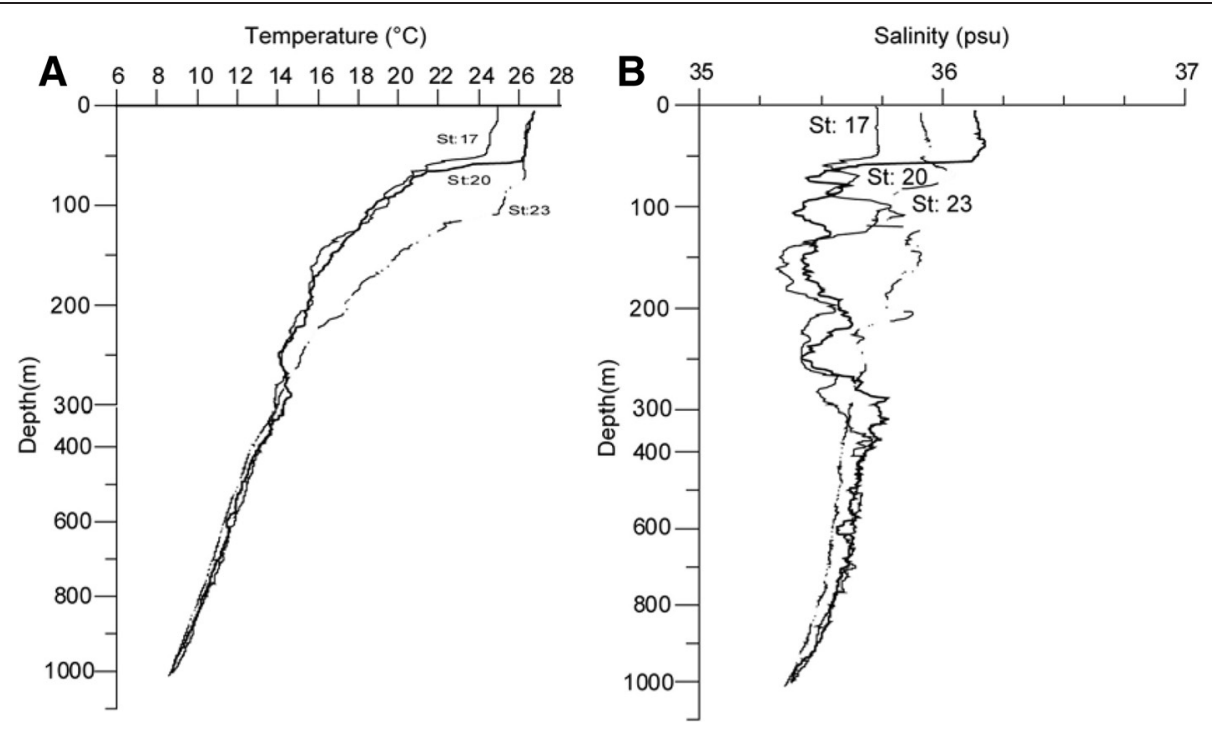

Figure 2 Vertical profiles of $(A)$ temperature $\left({ }^{\circ} \mathrm{C}\right)$ and $(B)$ salinity at the three locations.

\section{Phytoplankton cell abundance and composition (microscopic analyses of $>10 \mu \mathrm{m}$ cells)}

Numerically averaged cell proportion of diatoms in the phytoplankton community excluding Phaeocystis was lower at station $20(46 \%)$ than station $23(74 \%)$ and 17 (94\%; Figure 6A) indicating the overall dominance of diatoms at the two latter stations. It was interesting to find centric diatoms (chain forming in particular) dominating at station 20 (Table 1; Figure 6B, C). Further, dinoflagellate contribution at the swarm region (station 20) was the least (3\%; Figure 6D). Overall, phytoplankton diversity was also low at station 20: altogether, 22, 15, and 18 genera were recorded at stations 23,20 , and 17 , respectively (Table 1 ).
Phaeocystis distribution was patchy both geographically and vertically in the water column. They were found at surface (stations 17 and 23), $10 \mathrm{~m}$ (stations 20 and 23) and at $40 \mathrm{~m}$ (station 20). Maximum cell counts $(86 \times$ $10^{6} / \mathrm{L}$ ) were found at $10 \mathrm{~m}$ of station 23 and the least at station $17\left(0.01 \times 10^{6} / \mathrm{L}\right)$. At station 20 , Phaeocystis were found even at a deeper depth $\left(40 \mathrm{~m} ; 18.4 \times 10^{6} / \mathrm{L}\right)$. Their contribution to total phytoplankton abundance was sizable (see Figure 6A). At a few depths, their contribution to the total phytoplankton abundance was as high as 99.99\%. A near-surface maximum of Phaeocystis (52\% of the total phytoplankton abundance) was found only at station 17 (Figure 6A).
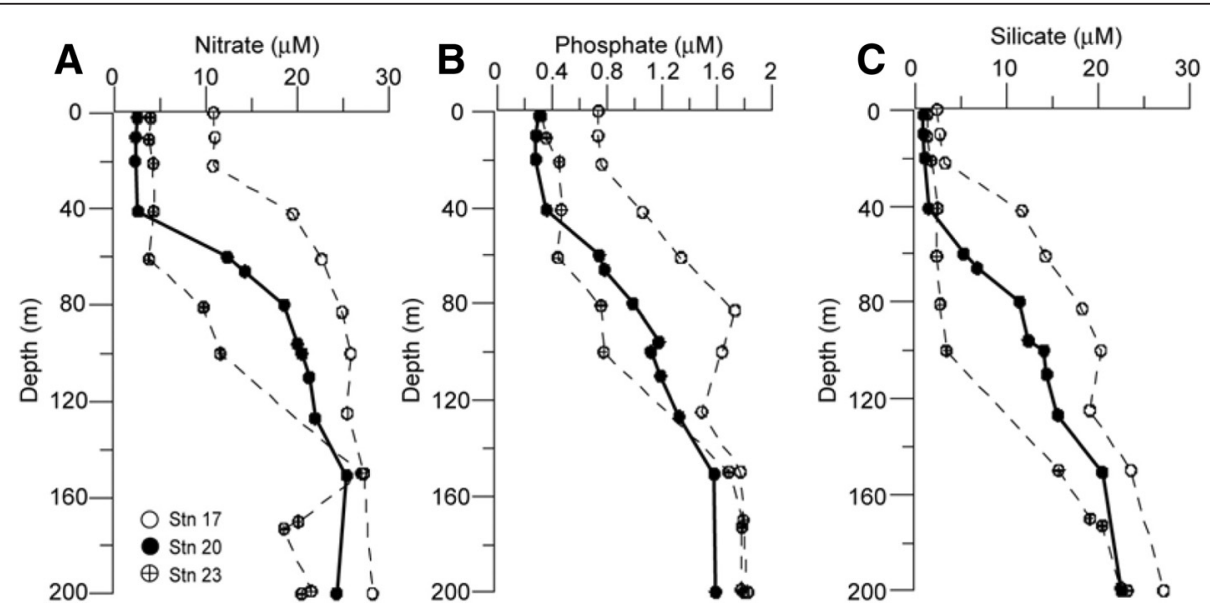

Figure 3 Vertical profiles of nutrients (A) nitrate, (B) phosphate, and (C) silicate at the three locations. 


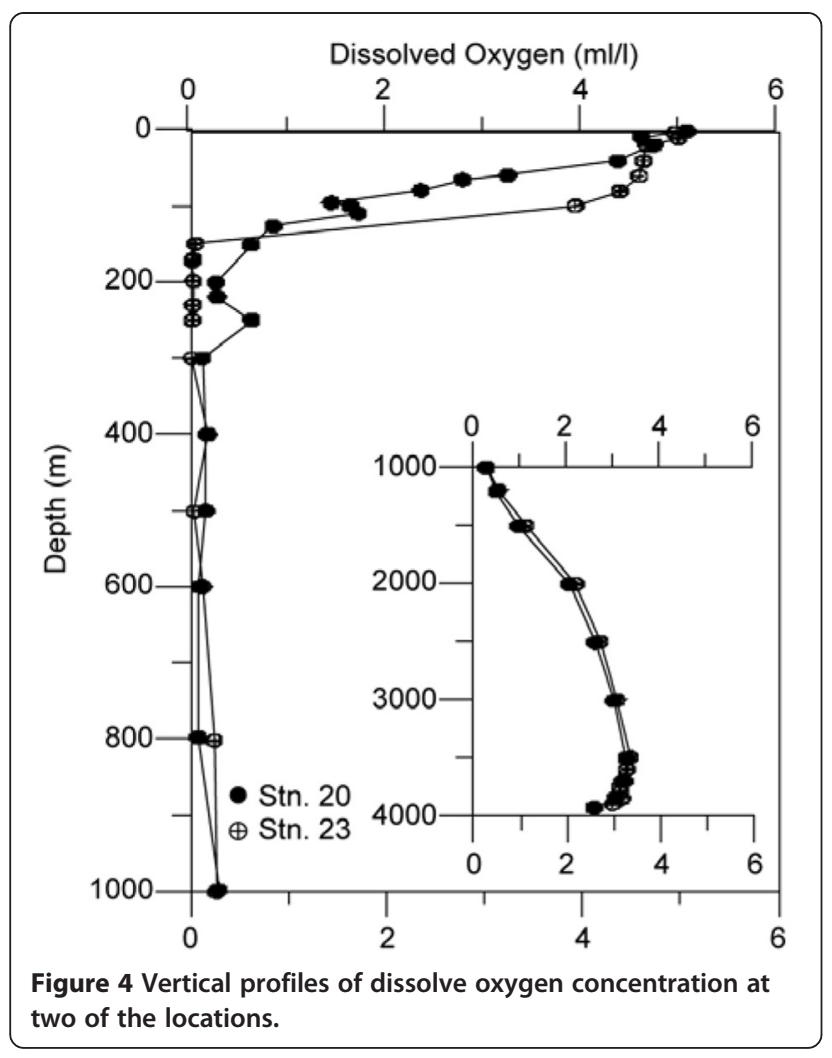

\section{Picophytoplankton (flow cytometry based)}

Flow cytometric data yielded a Synechococcus count at station 20 (approximately $20 \times 10^{6} / \mathrm{ml}$ at the surface) that was 2.5 and 9.5 times higher than the corresponding counts at stations 17 and 23, respectively (Figure 7A). Conversely, the number of picoeukaryotes were the least at station $20\left(0.12 \times 10^{6} / \mathrm{ml}\right)$, compared to the counts at the other sites of $0.15 \times 10^{6} / \mathrm{ml}$ at station 17 and $0.27 \times$ $10^{6} / \mathrm{ml}$ at station 23 (Figure $7 \mathrm{~B}$ ).

\section{Pigment analyses (HPLC based)}

Overall, phytoplankton pigments remained low, resembling nearly oligotrophic conditions. The pigmentderived diagnostic index (Figure 8), based on Barlow et al. (2007), revealed systematic differences in phytoplankton composition between stations (17, 20, and 23). Diat $_{\text {DP }}$ proportion ranged from 0.04 to 0.16 at station 20 and from 0.12 to 0.19 at station 23 , substantially lower than at station 17 (0.21 to 0.32). Dino ${ }_{D P}$ also showed a similar trend with minor increase below the surface at station 17. The Flag DP proportion representing the nanoflagellates was substantially higher than those of the larger phytoplankton groups, ranging between 0.41 and 0.58 . The Prok ${ }_{\mathrm{DP}}$ proportion, used to denote zeaxanthin containing cyanobacteria, showed significant increases at Stations 20 (and 23) suggesting the dominance of prokaryotes at these stations unlike station 17 where the Prok $_{D P}$ was low. Based on the diagnostic index, the order of dominance of phytoplankton groups at stations 20 and 23 was Flag $_{\mathrm{DP}}>$ Prok $_{\mathrm{DP}}>$ Diat $_{\mathrm{DP}}>$ Dino $_{\mathrm{DP}}$. At station 17, the order was Flag $g_{D P}>$ Diat $_{D P}>$ Dino $_{D P}>$ Prok $_{D P}$. Thus, flagellates appear to have been the most important autotrophs at all stations followed by cyanobacteria at stations 20 (and 23), and by diatoms at station 17.

\section{Bacterial abundance}

Bacterial abundance at station 20 (swarm site) was much lower as compared to non-swarm region even though in the upper water column their abundance showed a comparable vertical distribution at stations 20 and 23 (Figure 9A), except for an increase in abundance within the suboxic zone of station 23. Peak abundances found just below the surface (20 to $40 \mathrm{~m}$ ) at station 17 was approximately threefold higher $\left(1.1 \times 10^{9} / \mathrm{L}\right)$ than at stations 20 (and 23).

\section{Heterotrophic nanoflagellates}

Intriguingly, heterotrophic nanoflagellates (HNF) showed a trend different from that of bacterial abundance. In this case, abundance and depth profiles were similar for stations 17 and 23, but at station 20, a large increase in the HNF population occurred at $20 \mathrm{~m}$ depth $\left(0.17 \times 10^{7} / \mathrm{L}\right)$ with elevated numbers persisting down to at least $60 \mathrm{~m}$. Similar to the bacterial population, little differences were observed below $80 \mathrm{~m}$ depth (Figure 9B). There was a significant correlation (Figure 9C) between heterotrophic nanoflagellates and bacteria $(p<0.001, n=40)$, although the $r^{2}$ value was only 0.5 .

\section{Mesozooplankton}

Mesozooplankton ( $>200 \mu \mathrm{m}$ in size) abundance in the upper $1,000 \mathrm{~m}$ (0 to $200 \mathrm{mt} / 200$ to $1,000 \mathrm{~m})$ did not differ much between stations $17\left(2,349 / 1,579 \mathrm{~m}^{-3}\right)$ and 20 $\left(2,378 / 1,057 \mathrm{~m}^{-3}\right)$. On the other hand, abundance at station 23 was nearly twofold higher $\left(4,670 / 736 \mathrm{~m}^{-3}\right)$, particularly in the upper layer. Biomass also showed a similar trend with twofold higher values at station 23 ( $82 \mathrm{ml} / 100 \mathrm{~m}^{3}$; Table 1 ). Vertically, $88 \%$ to $97 \%$ of the biomass was in the upper $200 \mathrm{~m}$ (Figure 10A) particularly within the MLD. Overall, both numbers of organisms and their biomass decreased with increasing depth in the upper 1,000 $\mathrm{m}$ (Figure 10A).

Mesozooplankton composition in the region was dominated by 15 groups. Overall, diversity of these forms did vary between the stations. Most diverse forms belonged to copepoda family, such as Calanidae, Paracalanidae, Euchaetidae, Scolecitrichidae, Centropagidae, Temoridae, Acartidae, Candaciidae, Pontellidae, Aetideidae, Heterorhabdidae, Lucicutidae, Augaptilidae, Monstrillidae, Mormonillidae, and Metridinidae. Most abundant 

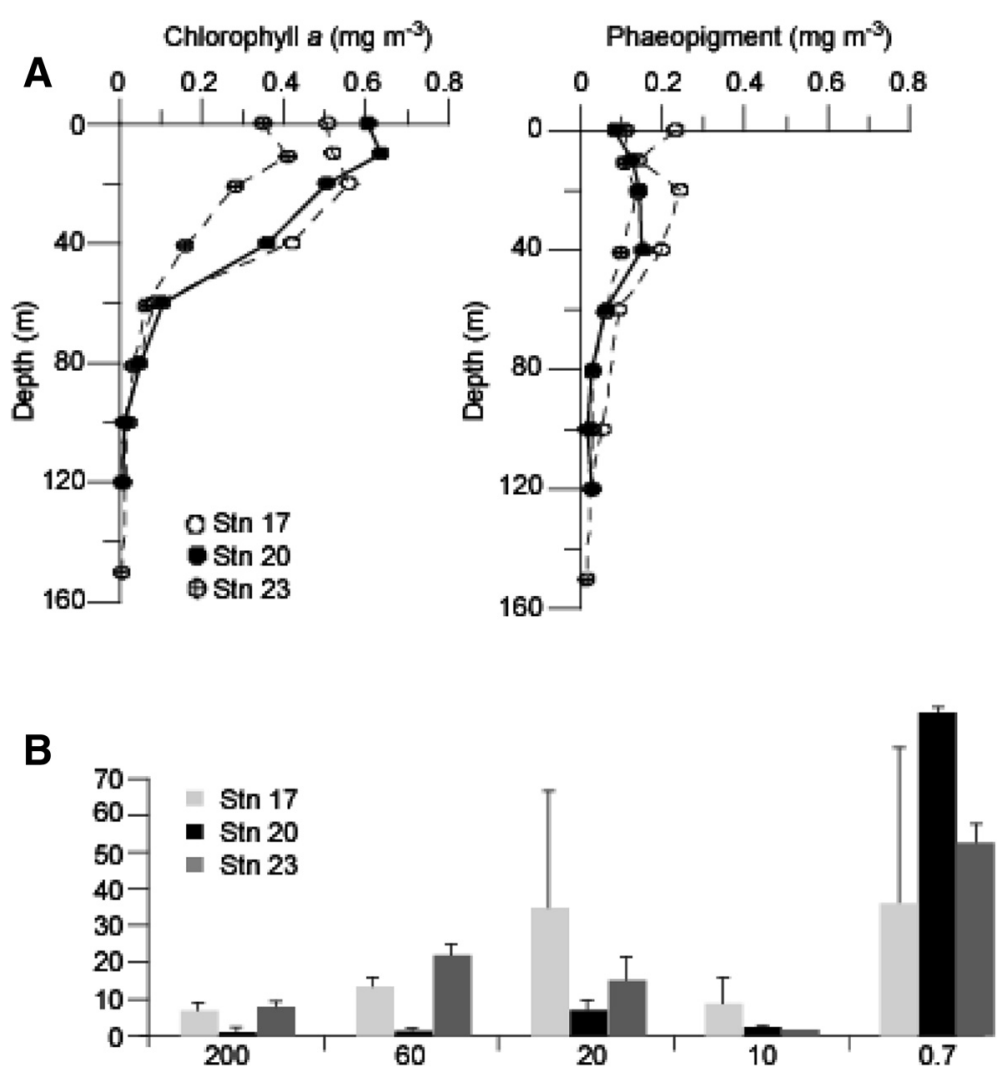

Figure 5 Vertical profiles of total and percent chlorophyll. (A) Total chlorophyll $a$ and phaeopments; (B) percent chlorophyll a biomass in different fractions $(\mu \mathrm{m})$ at different locations.

copepods present were Oncea spp., Corycaeus spp., and Paracalanus spp. while few representatives belonging to Cyclopoida, Poicilostomatoida, and Harpacticoida were also found (Table 2).

The integrated biomass and abundance data in the upper $120 \mathrm{~m}$ are plotted in Figure 10B. Total Chl $a$ biomass was relatively higher at stations 20 and 17 (average $\left.27 \mathrm{mg} / \mathrm{m}^{2}\right)$ compared to station $23\left(15.6 \mathrm{mg} / \mathrm{m}^{2}\right)$. In contrast, phytoplankton abundance of smaller forms $(<10 \mu \mathrm{m})$ dominated by Synechococcus was higher at station 20. The significance of Synechococcus is confirmed by flow cytometric and HPLC data. Possibly, observed high population of heterotrophic nanoflagellates was responsible for sustaining lower bacterial counts through grazing at station 20 (and also at station 23). Further, average biomass and abundance of mesozooplankton at stations 20 (and 17) was twofold lower than that at station 23 .

\section{Biochemical composition of pyrosomes}

The carbon and nitrogen contents of the pyrosome colonies, expressed as percent of dry weight, were 37.7 and 8.8, respectively. The molar $\mathrm{C}$-to- $\mathrm{N}$ ratio, thus works out to be 5.0. The isotopic values were $-19.91 \%$ o for $\delta^{13} \mathrm{C}$ and $7.43 \%$ for $\delta^{15} \mathrm{~N}$. The total protein concentration was approximately $134 \mathrm{mg} / \mathrm{g}$ dry wt.

\section{Discussion}

Generally, pyrosomes are strong diurnal migrators. During the day, they prefer the safety of the dark mesopelagic zone, while at night they migrate to the surface layer to feed on plankton (Angel 1989; Andersen et al. 1992). In the present study, the longest colony of approximately $2 \mathrm{~m}$ long was recovered at night from shallow depths. P. spinosum nearly of the same dimension was recovered accidentally with the CTD rosette in the North Atlantic during a cruise of G.O. Sars (see http://www.mareco.no/mareco_news/2004/the_pyrosome_story). A much longer $(6 \times 0.9 \mathrm{~m})$ colony of $P$. spinosum Herdman was reported from the New Zealand waters (Griffin and Yaldwyn 1970). The occurrence of P. spinosum at the surface during midday is possibly be due to the presence of a very shallow intense oxygen minimum zone (OMZ), which may act as a physical barrier for vertical movement in the entire North Indian Ocean. Similarly, no clear daynight migration pattern was recorded in Pyrosoma 


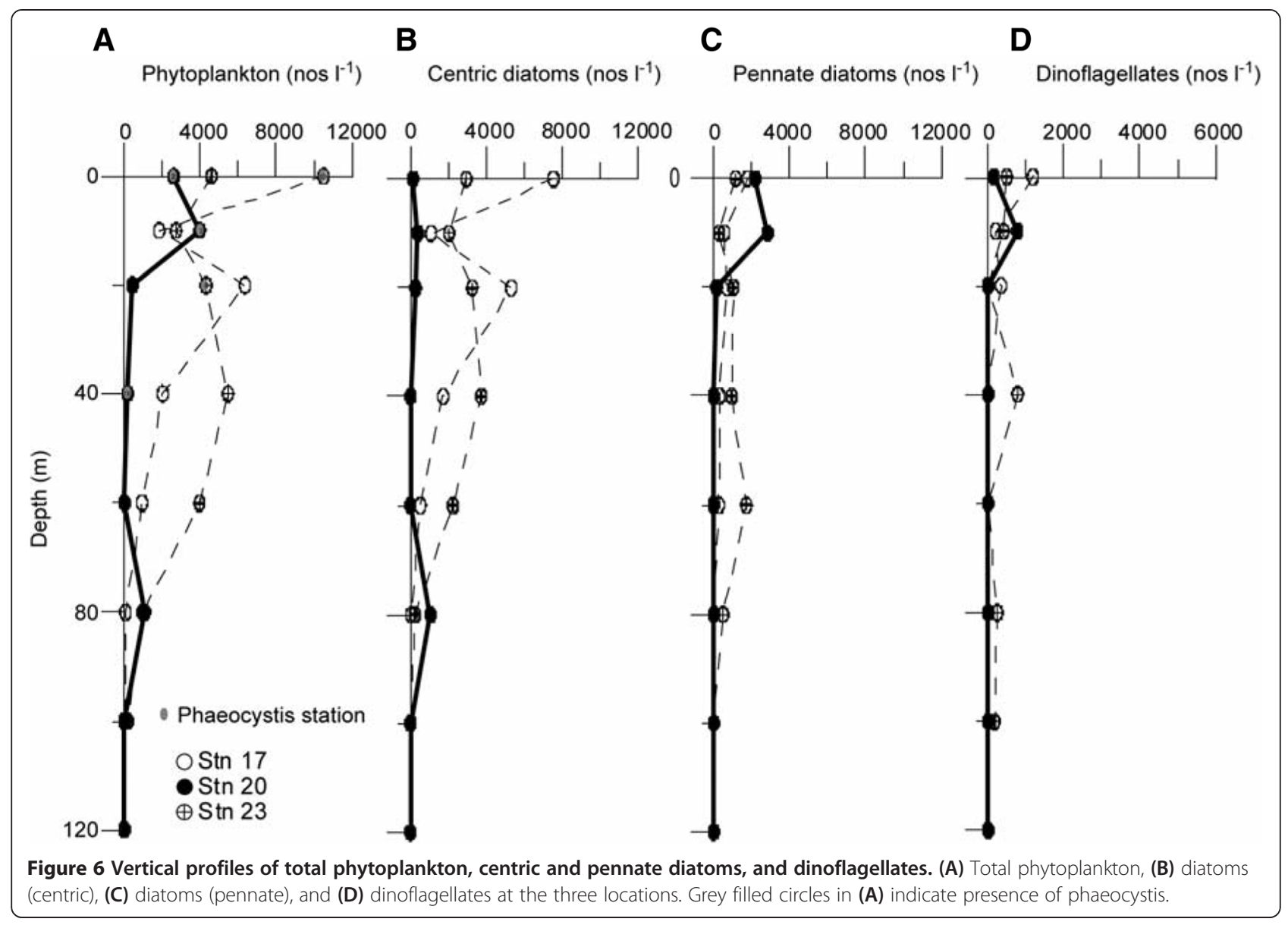

(not identified to the species level) in the open waters (along $88^{\circ} \mathrm{E}$ ) of the Bay of Bengal (Madhupratap et al. 2003), although the Pyrosoma colonies there were non tubular, smaller in size $(10 \times 10 \mathrm{~cm})$, fewer in number, and whitish in color.

As pointed out by Perissinotto et al. (2007), the trophic function, feeding dynamics, as well as ecology and physiology of pyrosomes are not well known. Analysis of gut contents of Pyrosoma (Hart, as cited by Culkin and Morris 1970) showed that the main food was phytoplankton (approximately $80 \%$ ) belonging to the classes Haptophyceae, Chrysophyceae, and Bacillariophyceae, the remainder was composed of protozoan species such as radiolarians and tintinnids. Consistent with this view, Bourguet et al. (2009) found higher values of Chl $a$ (38 $\pm 14.6 \mathrm{ng}$ Chl $a$ eq./mg dry weight) in the guts of $P$. atlanticum collected from the NW Mediterranean Sea. The question arises why the P. spinosum swarm occurred only at station 20 and not at the other two stations; where the physicochemical conditions were only slightly different? The map of the sea surface height anomaly overlaid with OSCAR surface current during the study period (Figure 11) depicts offshore advection of waters but no accumulation of water at the swarm site. Thus, one may argue that the swarm of pyrosome was driven by the biological factors. The low abundance of microphytoplankton (as determined by the microscopic counts) at station 20 are indicators of selective feeding of the swarms on the larger plankton-diatoms or that the resultant excretory products (note that the ammonium concentration was higher at the swarm site) might have supported a high population of Synechococcus and Phaeocystis. On the other hand, it is also possible that the higher abundance of cyanobacteria and flagellates at station 20 (low silica region) as seen from HPLC and flow cytometry data contributed to higher phytoplankton biomass (Chl $a$ content). A similar explanation for the occurrence of salps in the northern Arabian Sea has been invoked by Naqvi et al. (2002) who argued that a deficiency of silicate relative to nitrate limits diatom productivity in winter, a period of weak convection-driven vertical mixing. The data obtained in the present study confirm the postulation of Naqvi et al. (2010) that the high nitrate-to-silicate 
Table 1 Taxonomic list of phytoplankton ( $>5 \mu \mathrm{m}$ ) and their abundance at three different stations

\begin{tabular}{|c|c|c|c|c|c|}
\hline \multirow[b]{2}{*}{ Phytoplankton composition } & \multicolumn{2}{|l|}{ Station 17} & \multicolumn{2}{|l|}{ Station 20} & \multirow{2}{*}{$\begin{array}{l}\text { Station } 23 \\
\text { Cell } L^{-1} \\
(<100 \mathrm{mt})\end{array}$} \\
\hline & $\begin{array}{l}\text { Cell } \mathrm{L}^{-1} \\
(<100 \mathrm{mt})\end{array}$ & $\begin{array}{l}\text { Phytoplankton } \\
\text { composition }\end{array}$ & $\begin{array}{l}\text { Cell } \mathrm{L}^{-1} \\
(<100 \mathrm{mt})\end{array}$ & $\begin{array}{l}\text { Phytoplankton } \\
\text { composition }\end{array}$ & \\
\hline \multicolumn{6}{|l|}{ Diatom (centric) } \\
\hline Bacteriastrum delicatulum & 25 & Chaetoceros peruvianus & 24 & Chaetoceros spp. & 111 \\
\hline Chaetoceros coarctatus associated with vorticella & 42 & Corethron hystrix & 45 & Coscinodiscus spp. & 140 \\
\hline Chaetoceros messanensis & 85 & Fragilaria spp. & 152 & Fragilaria spp. & 75 \\
\hline Chaetoceros peruvianus & 25 & Rhizosolenia robusta & 25 & Planktoniella sol & 19 \\
\hline Chaetoceros spp. & 113 & Thalassiosira spp. & 89 & Pleurosigma spp. & 19 \\
\hline Coscinodiscus radiatus & 41 & & & Rhizosolenia alata & 408 \\
\hline Coscinodiscus eccentricus & 2 & & & Rhizosolenia hebetata & 152 \\
\hline Coscinodiscus spp. & 21 & & & Rhizosolenia imbricata & 157 \\
\hline Guinardia flaccida & 42 & & & Rhizosolenia robusta & 60 \\
\hline Guinardia striata & 42 & & & Rhizosolenia shrubsolei & 105 \\
\hline Leptocylindrus minimus & 190 & & & Rhizosolenia spp. & 11 \\
\hline Rhizosolenia alata & 404 & & & Rhizosolenia styliformis & 494 \\
\hline Rhizosolenia in association with vorticella & 98 & & & Thalassiosira spp. & 318 \\
\hline Rhizosolenia hebetata & 29 & & & & \\
\hline Rhizosolenia imbricata & 199 & & & & \\
\hline Rhizosolenia robusta & 31 & & & & \\
\hline Rhizosolenia setigera & 21 & & & & \\
\hline Rhizosolenia shrubsolei & 19 & & & & \\
\hline Rhizosolenia stolterfothii & 21 & & & & \\
\hline Rhizosolenia styliformis & 521 & & & & \\
\hline Rhizosolenia spp. & 21 & & & & \\
\hline Thalassiosira spp. & 337 & & & & \\
\hline \multicolumn{6}{|l|}{ Diatom (pennate) } \\
\hline Cocconeis spp. & 25 & Navicula spp. & 43 & Coconeis spp. & 38 \\
\hline Navicula directa & 21 & Nitzschia closterium & 136 & Navicula transitrans $f$. delicatula & 22 \\
\hline Navicula spp. & 155 & Nitzschia spp. & 66 & Navicula spp. & 49 \\
\hline Navicula transitrans f. delicatula & 10 & Pseudonitzschia spp. & 165 & Nitzschia closterium & 98 \\
\hline Nitzschia closterium & 21 & Thalassiothrix spp. & 443 & Nitzschia spp. & 198 \\
\hline Nitzschia spp. & 19 & & & Pseudonitzschia spp. & 151 \\
\hline Pleurosigma directum & 10 & & & Thalassiothrix longissima & 241 \\
\hline Pleurosigma spp. & 144 & & & & \\
\hline Pseudonitszchia spp. & 19 & & & & \\
\hline Thalassiothrix spp. & 85 & & & & \\
\hline \multicolumn{6}{|l|}{ Dinoflagellates } \\
\hline Ceratium fusus & 21 & Amphidinium spp. & 21 & Amphidinium spp. & 19 \\
\hline Ceratium horridum & 42 & Ceratium fusus & 21 & Amphisolenia bidentata & 46 \\
\hline Ceratium tripos & 34 & Gymnodium spp. & 24 & Ceratium tripos & 22 \\
\hline Goniodoma spp. & 21 & Gyrodinium spp. & 21 & Dinoflagellate cysts & 19 \\
\hline Gyrodinium spp. & 46 & Phalacroma rotundatum & 21 & Gonyaulax spp. & 22 \\
\hline Protoperidinium depressum & 42 & Prorocentrum dentatum & 21 & Gymnodium spp. & 46 \\
\hline Protoperidinium grande & 21 & Prorocentrum spp. & 21 & Gyrodinium spp. & 25 \\
\hline
\end{tabular}


Table 1 Taxonomic list of phytoplankton (>5 $\mu \mathrm{m}$ ) and their abundance at three different stations (Continued)

\begin{tabular}{|c|c|c|c|c|c|}
\hline Protoperidinium oceanicum & 10 & & & Podolampus spp. & 11 \\
\hline \multirow[t]{2}{*}{ Protoperidinium steinii } & 10 & & & Protoperidinium spp. & 46 \\
\hline & & & & Pyrophacus horologium & 42 \\
\hline \multicolumn{6}{|l|}{ Silicoflagellate } \\
\hline Dictyocha fibula & 19 & Dictyocha spp. & 27 & & \\
\hline \multicolumn{6}{|l|}{ Chrysophyceae } \\
\hline Phaeocystis spp. & 1,691 & Phaeocystis spp. & $6,986,667$ & Phaeocystis spp. & $12,285,714$ \\
\hline Total cells $\mathrm{L}^{-1}$ & 3,103 & & 1,367 & & 3,166 \\
\hline
\end{tabular}

ratio in upwelled waters, promotes the growth of smaller, non diatomaceous phytoplankton as the upwelled water advects offshore. The dominance of Phaeocystis in the aged offshore advecting upwelled silica deficient waters in the central Arabian Sea (close to the present study site) has been previously reported by Garrison et al. (1998). Typical succession of phytoplankton community from diatom to Phaeocystis appears to be a regular phenomenon in the open waters of the Arabian Sea during late southwest monsoon, which may attract the pelagic tunicates that are able to feed on small particles. Such bloom events are generally triggered by silicate depletion (Batje and Michaeles 1986; Verity et al. 1988) in the euphotic zone. Similar observations were also recorded in the upper $80 \mathrm{~m}$ water column at $15^{\circ} \mathrm{N} 64^{\circ} \mathrm{E}$ under the JGOFS (India) programme (1992 to 1997). At this site, undetectable silicate levels in the upper euphotic zone during southwest monsoon was dominated by Phaeocystis bloom (Madhupratap et al. 2000) unlike northeast monsoon where silicate concentration were relatively higher and largely dominated by diatoms in terms of its diversity (species of Nitzchia, Chaetoceros, and Rhizosolenia were predominant forms) and abundance (Sawant and Madhupratap 1996).

Signatures of the relative dominance of non-diatoms groups were also seen in the HPLC data indicating that nanoflagellates were dominant at subsurface waters of stations 20 and 23 with the characteristic pigment (hexanoyloxyfucoxanthin) found in the concentration range of 1 to $14 \mathrm{ng} / \mathrm{L}$; its concentration was low ( 1 to $4 \mathrm{ng} / \mathrm{L}$ ) at station 17. Further, zeaxanthin, which is a marker pigment of cyanobacteria, also contributed greatly to the total pigment pool $(7 \mathrm{ng} / \mathrm{L})$ at station 20 . All tunicates are suspension feeders and have the ability to take-up very small particles, including bacteria (Drits et al. 1992, Jørgensen and Goldberg 1953, Harbison and Gilmer 1976, Harbison and McAlister 1979). According to Drits et al. (1992), the minimum size of particles for the pyrosomes to feed should be of considerably $<3 \mu \mathrm{m}$. Salps,
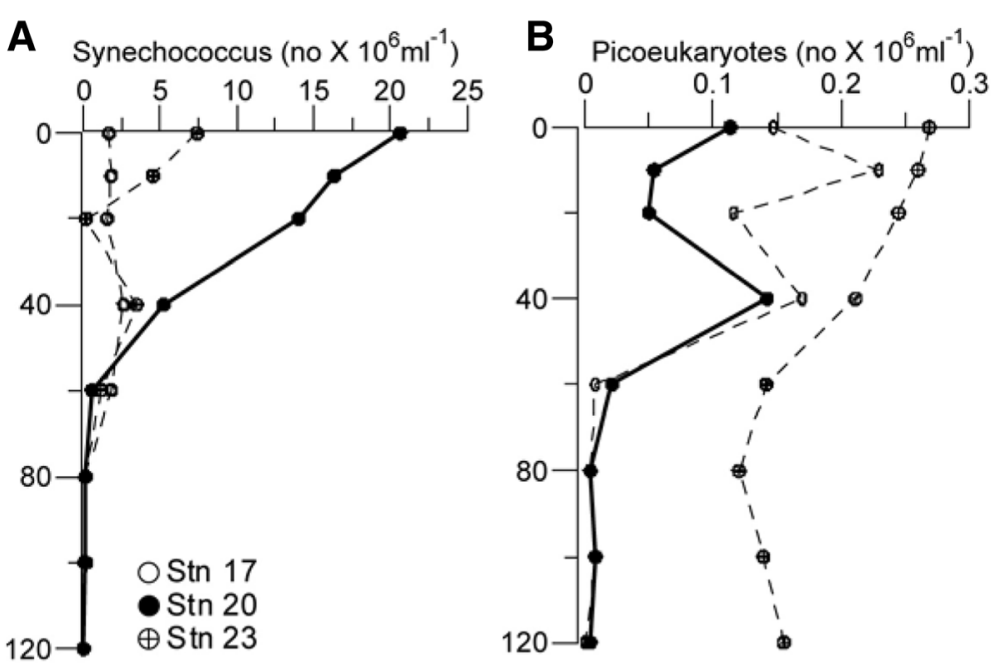

Figure 7 Vertical profiles of Synechococcus and picoeukaryotes. (A) Synechococcus $\left(\times 10^{6} / \mathrm{ml}\right)$ and (B) picoeukaryotes $\left(\times 10^{6} / \mathrm{ml}\right)$ abundance at the three locations. 

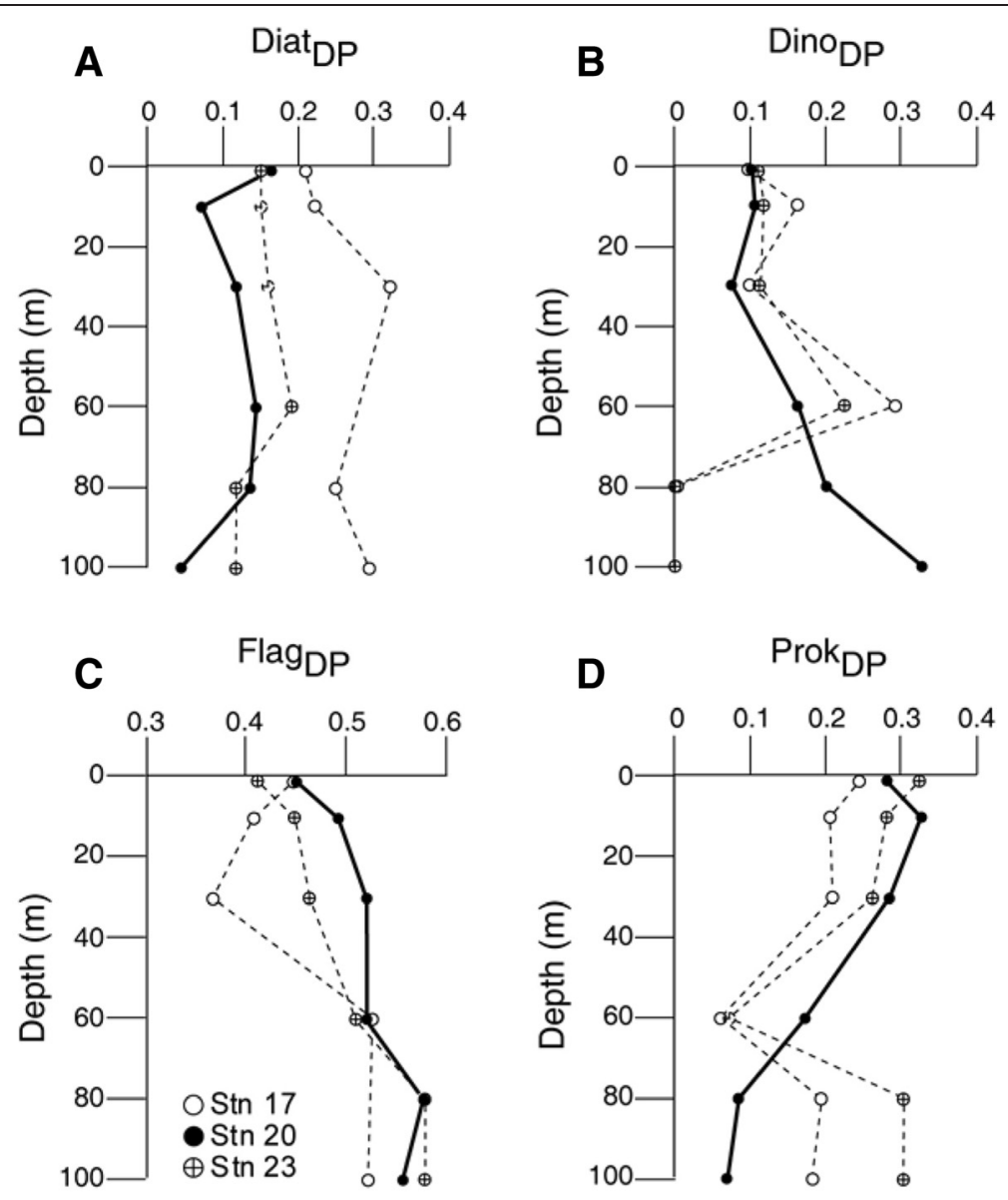

Figure 8 Dominant phytoplankton pigments (A) DiatDP, (B) DinoDP, (C) FlagDP, and (D) ProkDP at three locations.

perhaps the best known of all tunicates, are known to favor low-chlorophyll environments (Harbison et al. 1998) presumable to avoid clogging of their esophagus in high-chlorophyll waters dominated by large phytoplankton such as diatoms. With moderate chlorophyll levels and abundant small-sized autotrophs, we believe conditions prevailing at station 20 were best suited for the proliferation of tunicates in general. Thus, we favor the hypothesis that the pyrosome biomass was sustained by high densities of Synechococcus and flagellates that are of the right size (1 to $3 \mu \mathrm{m})$ to be retailed by tunicates and still not large enough to choke their filtration system.

The high clearance (Harbison and Gilmer 1976, Deibel 1988, Madin and Cetta 1984) and consumption rates make tunicates an important consumer of phytoplankton crop under swarm condition (Drits et al. 1992), due to which these colonial organisms produce very large quantities of faecal pellets and thus play an important role in the flux of organic carbon in the marine ecosystem (Esnal 1999). However, information available on their ingestion and particle clearance rate, particles/prey, and impact rates on planktonic biomass and production is sparse from the Arabian Sea. The tunicate work in the present study region is mostly restricted to the episodic swarms of salps (Lodh et al. 1998, Nair and Iyer 1974, Godeaux 1972, Naqvi et al. 2002, Ramaswamy et al. 2005). Ramaswamy et al. (2005) suggested that $36 \%$ of the PP was exported out of the surface layer largely through the sinking faecal pellets of salps. In the Southern Ocean, ingestion by salps has been reported to account for an even larger fraction (up to 100\%) of the PP (Dubischar and Bathmann 1997). Thus, we conclude that at the swarm site (station 20) fate of smaller-sized autotroph biomass was mostly recycling, supporting microbial food web.

Here, we attempted to estimate carbon processing by P. spinosum in the Arabian Sea based on the work of Drits et al. (1992) on P. atlanticum from off the Congo River mouth, even though these two tunicates are not very similar morphologically. We used the following values: filtration efficiency $=3$ to $7.2 \mathrm{~L}$ ind ${ }^{-1} \mathrm{~h}^{-1}$ ); 

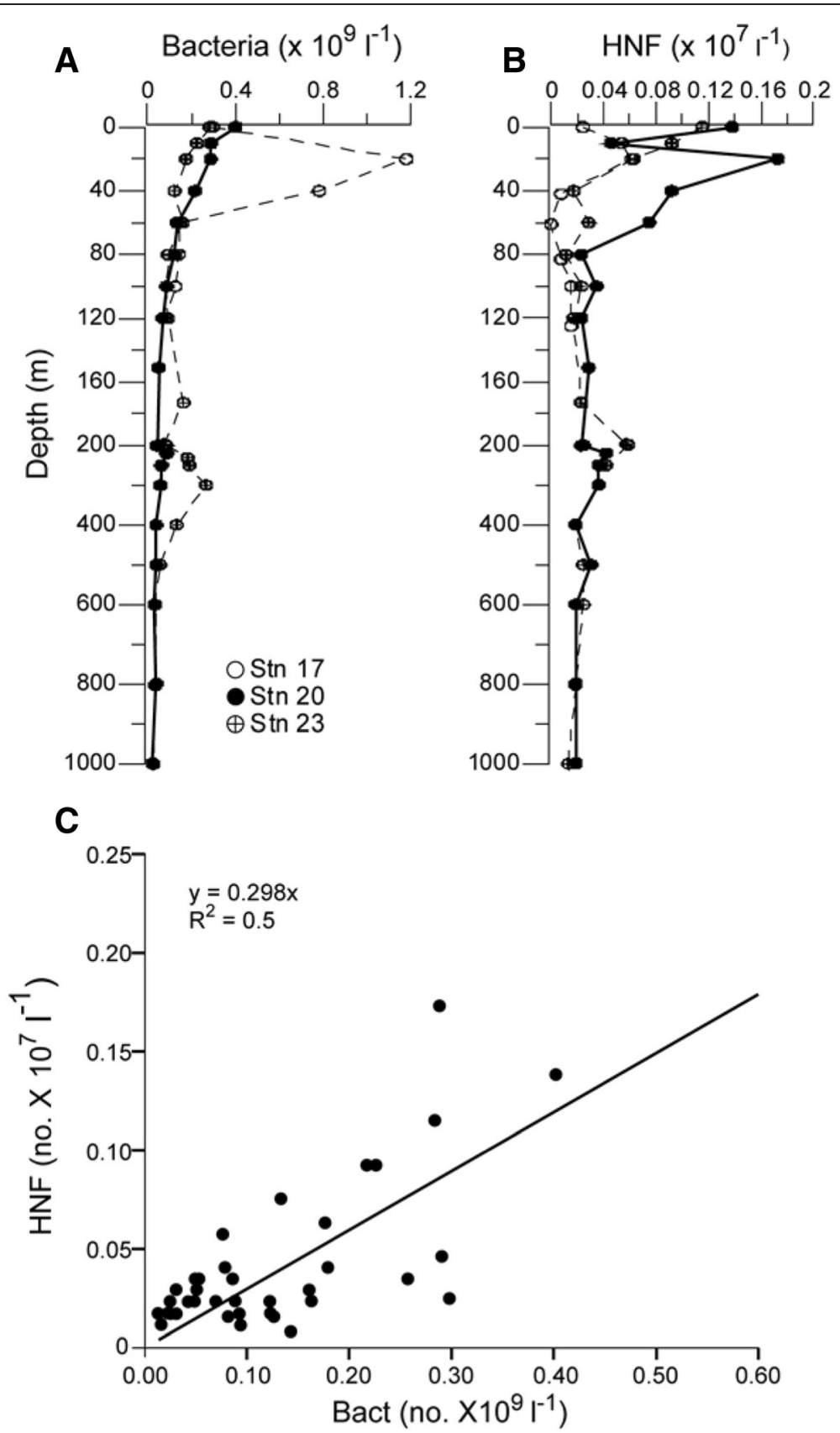

Figure 9 Abundance of (A) bacteria, (B) heterotrophic nanoflagellates at the three locations, and (C) their coupling.

ingestion $=4 \%$ to $53 \%$ of the phytoplankton standing stock; rate of fecal pellet production $=1.4$ to 2.2 pellets $\mathrm{h}$ ${ }^{-1}$ zooid $^{-1}$ (this rate is similar to that for salps; Ramaswamy et al. 2005); dry weight of each pellet $=2 \mu \mathrm{g}$; carbon content $=22 \%$ of the dry weight, and sinking rate of pellets $=70 \mathrm{~m} \mathrm{~d}^{-1}$ (this is 6 to 12 times slower than that of salps; Ramaswamy et al. 2005). For 24 h, we calculated that a tubular colony having a dimension of $50 \times$ $150 \mathrm{~cm}$ (with 50,000 zooids) would produce $1.7 \times 10^{6}$ to
$2.6 \times 10^{6}$ pellets $\mathrm{d}^{-1}$. The amount of water filtered by such a colony would be 3.6 to $8.6 \times 10^{6} \mathrm{~L} \mathrm{~d}^{-1}$. The contribution of such a colony to carbon export from the surface layer would be 0.74 to $1.16 \mathrm{~g} \mathrm{C} \mathrm{d}^{-1}$. In general, this highlights key role of tunicates in the marine carbon cycle. Readers should use caution when interpreting these estimates. Further, due to the episodic nature of the swarms the significance of pyrosomes to the total carbon export from the surface layer cannot be 

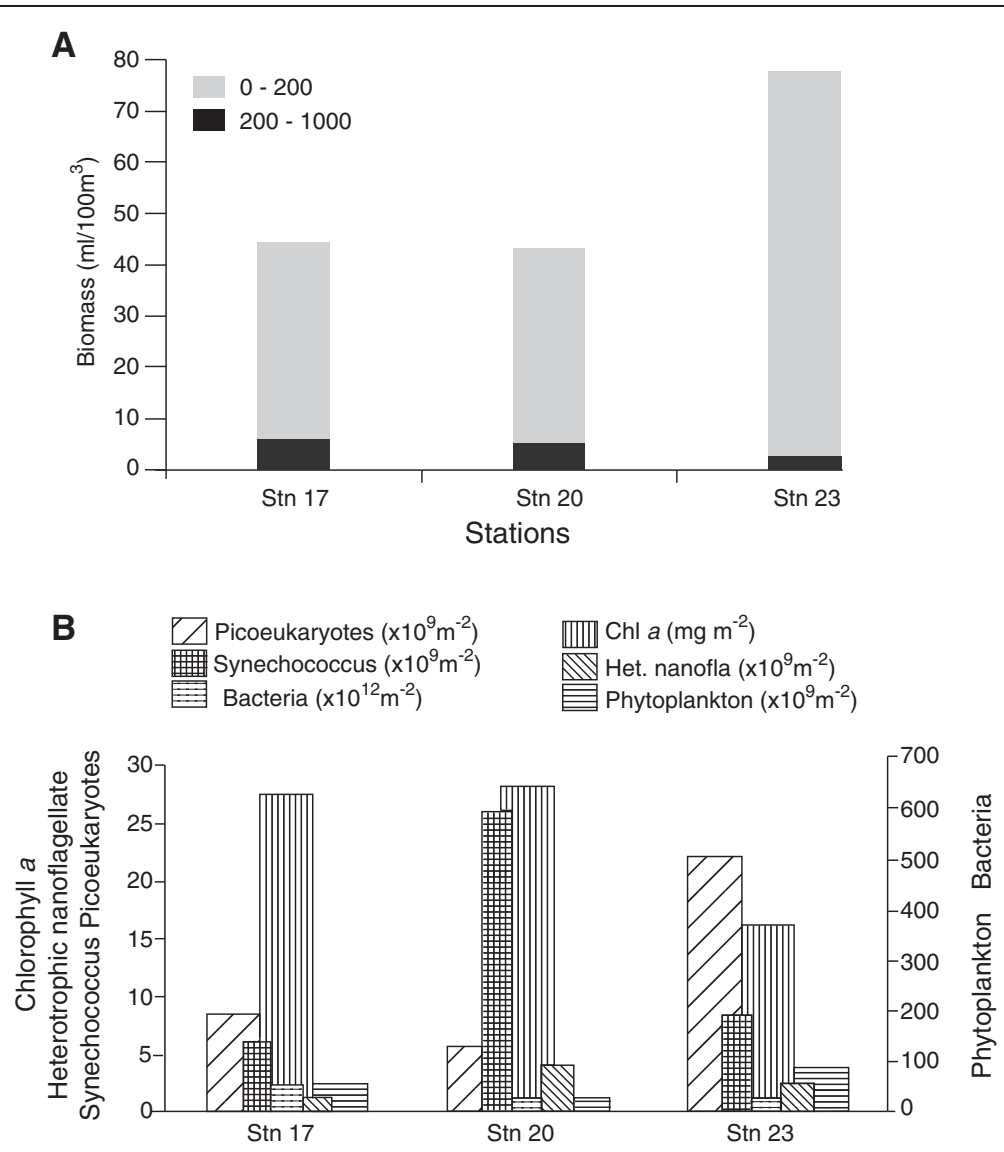

Figure 10 Vertical distribution Mesozooplankton biomass (A) and (B) depth integrated abundance of phytoplankton ( $>5 \mathrm{~m} \mu)$, het nanoflagellates, het. Bacteria (Bacteria), picoeukaryotes, Synechococcus, and chlorophyll a concentration (Chl a) in upper $100 \mathrm{mt}$ water column at the three different locations.

quantified. In addition to the flux through faecal pellets, sinking of dead colonies is also known to contribute to carbon export. For example, photographs taken at a depth of 5,540 $\mathrm{m}$ at the bottom of the Madeira Abyssal Plain showed the arrival of dead Pyrosoma on the sea bed, where it was consumed by echinoderms, cnidarians, and arthropods, reflecting the considerable ecological influence of such organisms on the food web in the deep sea (Lampitt et al. 2001).

$P$. spinosum, similar to $P$. atlanticum, was also found to have a high carbon content (37\% of dry weight). The nitrogen content was estimated to be $17 \%$ of dry weight. Both carbon and nitrogen contents are higher than reported by Larson (1986) for gelatinous zooplankton including thaliaceans. The molar $\mathrm{C}$-to- $\mathrm{N}$ ratio (5) in $P$. spinosum is higher than the value (4) for $P$. atlanticum reported by Gabriel et al. (1988). Yet, this value is lower than the Redfield ratio (6.6), presumably because of the more proteinaceous nature of pyrosomes relative to 'average' marine organic matter. Nonetheless, the protein content of $P$. spinosum obtained by us $(134 \mathrm{mg} / \mathrm{g})$ is lower than the values reported previously (e.g., $355 \mathrm{mg} / \mathrm{g}$; Raymont et al. 1975). Further, the $\mathrm{C}$ and $\mathrm{N}$ isotopic values of Pyrosoma tissue (-19.91\%o for $\delta^{13} \mathrm{C}$ and $7.43 \%$ for $\delta^{15} \mathrm{~N}$ ) are slightly higher than the average marine organic matter. The high carbon and protein contents in their dry weight indicate their potential value as a food source for predators in the ecosystem. Previous work of Harbison (1998), James and Stahl (2000), Childerhouse et al. (2001), and Hedd and Gales (2001) demonstrated that pyrosomes are actually a very important prey item in the diet of many marine mammals, fish, turtle and also albatross, and sea lion.

On the other hand, saphiriniid mysterious parasitic copepods have often been found to be associated with pyrosome colonies (Harbison 1998, Tregouboff and Rose 1957, Monticelli and Lo Bianco 1901, Lindley et al. 2001) including north-western Indian Ocean (Rajaram and Krishnaswamy 1980). In the present study, species of Sappharina (darwinii and metallina) were not found at station 20, but they were present at the other two stations (stations 17 and 23) where the swarm was not found. The absence of these parasitic species at station 
Table 2 Taxonomic list of mesozooplankton (>200 $\mu \mathrm{m}$ ) and their abundance at three different stations

\begin{tabular}{llll}
\hline $\begin{array}{l}\text { Mesozooplankton (copepod) } \\
\text { composition }\end{array}$ & 0 to $200 \mathrm{mt}\left(\mathrm{org} / 100 \mathrm{~m}^{3}\right)$ \\
\cline { 2 - 4 } & Station & Station & Station \\
& 23 & 20 & 17 \\
\hline
\end{tabular}

Calanoida

Calanidae

Canthocalanus pauper

Cosmocalanus darwini

Calanoides carinatus

Undinula vulgaris

Calanus spp.

Eucalanidae

Eucalanus attenuatus

Eucalanus subcrassus

Eucalanus spp.

Rhincalanus cornutus

Rhincalanus nasutus

Paracalanidae

Acrocalanus gibber

Acrocalanus sp.

Paracalanus spp.

Calocalanus pavo

Calocalanus sp.

Euchaetidae

Euchaeta concinna

Euchaeta wolfendeni

Euchaeta marina

Euchaeta spp.

Scolecithricidae

Scolecithricella spp.

Scaphocalanus spp.

Scottocalanus helenae

Lophothrix frontalis

Centropagidae

Centropage furcatus

Temoridae

Temora stylifera

Temora discaudata

Acartiidae

Acartia spp.

Acartia erythraea

Clausocalanidae

Clausocalanus furcatus

Candaciidae

Candacia pachydactyla

*

Table 2 Taxonomic list of mesozooplankton ( $>200 \mu \mathrm{m}$ ) and their abundance at three different stations (Continued)

\begin{tabular}{|c|c|c|c|}
\hline Candacia curta & 1 & - & - \\
\hline Candacia bradyi & $*$ & 1 & - \\
\hline \multicolumn{4}{|l|}{ Pontellidae } \\
\hline Labidocera acuta & 1 & - & - \\
\hline Labidocera minuta & $*$ & - & - \\
\hline Labidocera sp. & 3 & - & 1 \\
\hline Calanopia sp. & 1 & 1 & - \\
\hline \multicolumn{4}{|l|}{ Aetideidae } \\
\hline Aetideus sp. & - & * & $*$ \\
\hline Euchirella amoena & * & * & - \\
\hline Euchirella maxima & - & * & - \\
\hline Euaetideus giesbrechti & - & - & $*$ \\
\hline \multicolumn{4}{|l|}{ Augaptiliidae } \\
\hline Euaugaptilus hecticus & - & - & $*$ \\
\hline Haloptilus spp. & - & - & $*$ \\
\hline \multicolumn{4}{|l|}{ Heterohabdidae } \\
\hline Heterohabdus sp. & * & 1 & 1 \\
\hline \multicolumn{4}{|l|}{ Lucicutiidae } \\
\hline Lucicutia flavicornis & 2 & * & 1 \\
\hline Lucicutia ovalis & * & * & 1 \\
\hline \multicolumn{4}{|l|}{ Mormonillidae } \\
\hline Mormonilla phasma & $*$ & 1 & \\
\hline Mormonilla minor & - & * & 1 \\
\hline \multicolumn{4}{|l|}{ Metridinidae } \\
\hline Pleuromamma (juveniles) & - & 3 & - \\
\hline Pleuromamma xiphias & - & $*$ & - \\
\hline Pleuromamma indica & 2 & - & - \\
\hline Pleuromamma gracilis & 1 & $*$ & 2 \\
\hline \multicolumn{4}{|l|}{ Cyclopoida } \\
\hline \multicolumn{4}{|l|}{ Oithonidae } \\
\hline Oithona plumifera & 2 & 3 & 1 \\
\hline Oithona sp. & 6 & 4 & 3 \\
\hline Oithona helgolandicus & - & 1 & - \\
\hline Saphirella tropica & - & * & - \\
\hline \multicolumn{4}{|l|}{ Poicilostomatoida } \\
\hline \multicolumn{4}{|l|}{ Corycaeidae } \\
\hline Corycaeus catus & 1 & - & 1 \\
\hline Corycaeus sp. & 21 & 6 & 6 \\
\hline Farranula gracilis & 1 & - & $*$ \\
\hline Faranula spp. & 5 & 1 & - \\
\hline \multicolumn{4}{|l|}{ Oncaeidae } \\
\hline Oncaea sp. & 26 & 29 & 14 \\
\hline
\end{tabular}


Table 2 Taxonomic list of mesozooplankton (>200 $\mu \mathrm{m}$ ) and their abundance at three different stations (Continued)

\begin{tabular}{|c|c|c|c|}
\hline Sapphirina spp. & - & - & * \\
\hline Sapphirina gastrica & - & - & 1 \\
\hline Sapphirina darwini & * & - & - \\
\hline Sapphirina metallina & * & - & - \\
\hline Copilia mirabilis & 4 & - & * \\
\hline Vettoria granulosa & $*$ & - & - \\
\hline \multicolumn{4}{|l|}{ Harpacticoida } \\
\hline \multicolumn{4}{|l|}{ Clytemnestridea } \\
\hline Clytemnestra scutellata & $*$ & 1 & 1 \\
\hline \multicolumn{4}{|l|}{ Euterpinidae } \\
\hline Euterpina acutifrons & 1 & - & 1 \\
\hline \multicolumn{4}{|l|}{ Miraciidae } \\
\hline Macrosetella gracilis & $*$ & - & - \\
\hline \multicolumn{4}{|l|}{ Ectinosomatidae } \\
\hline Microsetella rosea & - & 1 & - \\
\hline Microsetella norvegica & - & - & 1 \\
\hline Copepode nauplii & 3 & 3 & 2 \\
\hline Juvenile copepod & 4 & - & - \\
\hline
\end{tabular}

20 may be an additional reason for sustaining the prevalence of $P$. spinosum swarm.

\section{Conclusions}

During the middle of the day, a pyrosome swarm was observed in the surface waters of the central Arabian Sea. Presence of the perennial oxygen minimum zone at subsurface depth may have restrain pyrosomes from migrating into the deeper layer. Biological factors predominantly seem to have sustained pyrosome swarm. At the swarm site, surface water advected from the coastal upwelling region or entrained from the thermocline characterized by low silicate, and high nitrate and ammonia concentrations perhaps promoted the growth of smaller, non-diatomaceous phytoplankton. Since tunicates have the ability to take-up very small particles, the high densities of Synechococcus and flagellates that are of the right size ( 1 to $3 \mu \mathrm{m}$ ) appear to have offered favorable condition for nourishment of these filter feeders $P$. spinosum. The absence of parasitic species of copepods Sappharina (darwinii and metallina) may be an additional reason for sustaining the prevalence of $P$. spinosum swarm. Overall, the occurrence and importance of tunicates such as pyrosomes have been largely overlooked in the northern Indian Ocean and warrant further investigations.

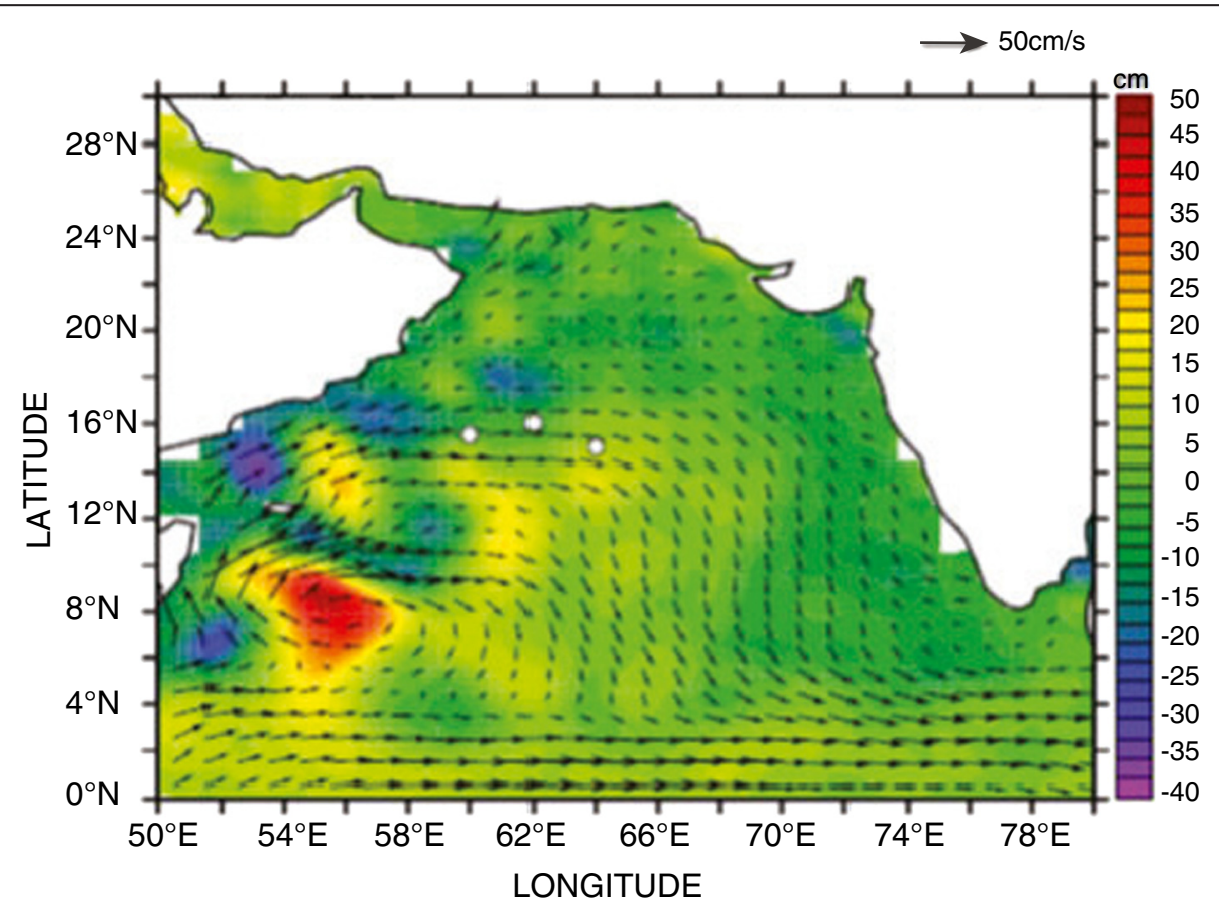

Figure 11 Spatial map of sea surface height anomaly (cm) (shading) overlaid with OSCAR surface current (arrows) during 12 September 2007. White circles represent station locations. 


\section{Additional file}

Additional file 1: Photograph showing floating Pyrosoma spinosum swarms in the surface waters of station 20. (A) Floating colony; (B) colony caught CTD; (C) colony on deck; (D) closer view of colony under microscope; (E) zooids under bright field; and (F) zooids under dark field.

\section{Competing interests}

The authors declare that they have no competing interests.

\section{Authors' contributions}

MG participated in sample collection and analysis of some of biological parameters and drafted and revised manuscript. SM participated in the cruise and carried out analysis of phytoplankton and zooplankton taxonomy. AP participated in the cruise and carried out chemical measurements. RR participated in the cruise and carried out HPLC-based pigment analyses. SWAN led the cruise, carried out chemical analysis, and helped in drafting and editing of the previous versions of manuscript. All authors read and approved the final manuscript.

\section{Acknowledgements}

The authors thank the director of CSIR-NIO for his encouragement in carrying out this study. The authors wish to thank the CSIR (India) for financial support. This work was carried out as a part of network programmes 'CMM0009' and 'NWP 0014'. We thank Mrs. Supriya Karapurkar for elemental/isotopic analyses of samples and Dr. Catherine Sumathi for protein estimation. We are grateful to the captain and crew of R.V. Roger Revelle for their help in deck operations and to our colleagues for their assistance in sampling and analysis. This is NIO contribution no. 5684.

\section{Received: 30 May 2014 Accepted: 14 November 2014}

\section{Published online: 03 January 2015}

\section{References}

Alldredge AL (1981) The impact of appendicularian grazing on natural food concentrations in situ. Limnol Oceanogr 26:247-257

Andersen V, Sardou J, Nival P (1992) The diel migrations and vertical distributions of zooplankton and micronekton in the Northwestern Mediterranean Sea. 2. Siphonophores, hydromedusae and pyrosomids. J Plankton Res 14:1155-1169

Angel MV (1989) Vertical profiles of pelagic communities in the vicinity of the Azores Front and their implications to deep ocean ecology. Prog Oceanogr 22(1):24

Barlow R, Stuart V, Lutz V, Sessions H, Sathyendranath S, Platt T, Kyewalyanga M, Clementson L, Fukasawa M, Watanabe S, Devred E (2007) Seasonal pigment patterns of surface phytoplankton in the subtropical southern hemisphere. Deep Sea Res I 54:1687-1703

Bary BM (1960) Notes on the ecology, distribution and systematics of pelagic Tunicata from New Zealand. Pac Sci 14:101-121

Bätje M, Michaelis H (1986) Phaeocystis pouchetii blooms in the East Frisian coastal waters (German Bight, North Sea). Mar Biol 93:21-27

Booth BC, Lewin J, Postel JR (1993) Temporal variation in the structure of autotrophic and heterotrophic communities in the subarctic pacific. Prog Oceanogr 32:57-99

Bourguet N, Goutx M, Ghiglione J, Pujo-Pay M, Mével G, Momzikoff A, Mousseau L, Guigue C, Garcia N, Raimbault P, Pete R, Oriol L, Lefèvre D (2009) Lipid biomarkers and bacterial lipase activities as indicators of organic matter and bacterial dynamics in contrasted regimes at the DYFAMED site, NW Mediterranean. Deep Sea Res II 56:1454-1469

Bradford MM (1976) A rapid and sensitive method for the quantitation of microgram quantities of protein utilizing the principle of protein-dye binding. Anal Biochem 72:248-254

Brown SL, Landry MR, Barber RT, Campbell L, Garrison DL, Gowing MM (1999) Picophytoplankton dynamics and production in the Arabian Sea during the 1995 Southwest Monsoon. Deep Sea Res II 46:1745-1768

Childerhouse S, Dix B, Gales N (2001) Diet of New Zealand sea lions (Phocarctos hookeri) at the Auckland Islands. Wildl Res 28:291-298

Culkin F, Morris RJ (1970) The fatty acids of some cephalopods. Deep Sea Res $17: 171-174$
Deibel D (1982) Laboratory-measured grazing and ingestion rates of the salp, Thalia democratica Forskal, and the doliolid, Dolioletta gegenbauri Uljanin (Tunicata, Thaliacea). J Plankton Res 4:189-201

Deibel D (1986) Feeding mechanism and house of the appendicularian Oikopleura vanhoeffeni. Mar Biol 93:429-437

Deibel D (1988) Filter feeding by Oikopleura vanhoeffeni, grazing impact on suspended particles in cold ocean waters. Mar Biol 99:177-187

Drits AV, Arashkevich EG, Semenova TN (1992) Pyrosoma atlanticum (Tunicata, Thaliacea): grazing impact on phytoplankton standing stock and role in organic carbon flux. J Plankton Res 14:799-809

Dubischar CD, Bathmann UV (1997) Grazing impact of copepods and salps on phytoplankton in the Atlantic sector of the Southern Ocean. Deep Sea Res II 44:415-433

Esnal G (1999) Pyrosomatida. In: Boltovskoy D (ed) South Atlantic Zooplankton. Backhuys Publishers, Leiden, pp 1423-1444

Gabriel G, Dallot S, Sardou J, Fenaux R, Claude C, Isabelle P (1988) C and N composition of some northwestern Mediterranean zooplankton and micronekton species. J Exp Mar Biol Ecol 124:133-144

Garrison DL, Gowing MM, Hughes MP (1998a) Nano- and microplankton assemblages in the northern Arabian Sea during the Southwestern Monsoon, AugustSeptember, 1995: a US JGOFS study. Deep-Sea Res II 45:2269-2299

Godeaux J (1972) Pelagic tunicates of the Indian Ocean. J Mar Biol Ass India 14:263-292

Griffin DJG, Yaldwyn JC (1970) Giant colonies of pelagic tunicates (Pyrosoma spinosum) from SE Australia and New Zealand. Nature 226(5244):464

Haas LW (1982) Improved epifluorescence microscopy for observing planktonic organisms. Ann Inst Oceanogr Paris 58:261-266

Harbison GR (1998) The parasites and predators of Thaliacea. In: Bone Q (ed) The biology of pelagic tunicates. Oxford University Press, Oxford, pp 187-214

Harbison GR, Gilmer RW (1976) The feeding rates of the pelagic tunicate, Pegea confoederata, and two other salps. Limnol Oceanogr 21:517-528

Harbison GR, McAlister VL (1979) The filter feeding rates and particle retention efficiencies of three species of Cyclosalpa (Tunicata, Thaliacea). Limnol Oceanogr 24:875-892

Hedd A, Gales R (2001) The diet of shy albatrosses (Thalassarche cauta) at Albatross Island. Tasmania J Zool London 253:69-90

Indian Ocean Biological Centre (1973) International Indian Ocean Expedition Plankton Atlas. In: Panikkar NK (ed). UNESCO/NIO, 4(2)

James JD, Stahl JC (2000) Diet of southern Buller's albatross (Diomedea bulleri bulleri) and the importance of fishery discards during chick rearing. N Z J Mar Freshw Res 34(3):435-454

Jørgensen CB, Goldberg ED (1953) Particle filtration in some ascidians and lamellibranchs. Biol Bull 105:477-489

Lampitt RS, Bett BJ, Kiriakoulakis K, Popova EE, Ragueneau O, Vangriesheim A, Wolff GA (2001) Material supply to the abyssal seafloor in the northeast Atlantic. Prog Oceanogr 50:27-63

Larson RJ (1986) Water content, organic content, and carbon and nitrogen composition of medusae from the northeast Pacific. J Exp Mar Biol Ecol 99:107-120

Lindley JA, Hernández F, Scatllar J, Docoito J (2001) Funchalia sp. (Crustacea: Penaeidae) associated with Pyrosoma atlanticum (Thaliacea: Pyrosomidae) off the Canary Islands. J Mar Biol Assoc UK 81:173-174

Lodh NM, Gajbhiye SN, Nair V (1998) Unusual congregation of salps off Verval and Bombay. West Coast of India Indian J Mar Sci 17:128-130

Madhupratap M, Sawant S, Gauns M (2000) First report on a bloom of the marine prymnesiophycean, Phaeocystis globosa from the Arabian Sea. Oceanol Acta 23(1):83-90

Madhupratap M, Gauns M, Ramaiah N, Prasanna Kumar S, Muraleedharan PM, De Sousa SN (2003) Biogeochemistry of the Bay of Bengal: physical, chemical and primary productivity characteristics of the central and western Bay of Bengal during summer monsoon 2001. Deep-Sea Res II 50:881-896

Madin LP (1982) The production, composition and sedimentation of salp fecal pellets in oceanic waters. Mar Biol 67:39-45

Madin LP, Cetta CM (1984) The use of gut fluorescence to estimate grazing by oceanic salps. J Plankton Res 6:475-482

Millar RH (1971) The biology of ascidians. Adv Mar Biol 9:1-100

Monticelli FS, Lo Bianco S (1901) Sullo sviluppo dei peneididel Golfo di Napoli (note riassuntive). Monit Zool Ital 11:23-31 (in Italian)

Morrison JM, Codispoti LA, Smith SL, Wishner K, Flagg C, Gardner WD, Gaurin S, Naqvi SWA, Manghnani V, Prosperie L, Gundersen JS (1999) The oxygen minimum zone in the Arabian Sea during 1995. Deep-Sea Res II 46:1903-1931 
Nair VR, lyer HK (1974) Quantitative distribution of copelates, salps and doliolids (Pelagic tunicates) in Indian Ocean. Indian J Mar Sci 3:150-154

Naqvi SWA, Sarma WSS, Jayakumar DA (2002) Carbon cycling in the northern Arabian Sea during the northeast monsoon: significance of salps. Mar Ecol Prog Ser 226:35-44

Naqvi SWA, Moffett JW, Gauns MU, Narvekar PV, Pratihary AK, Naik H, Shenoy DM, Jayakumar DA, Goepfert TJ, Patra PK, Al-Azri A, Ahmed SI (2010) The Arabian Sea as a high-nutrient, low-chlorophyll region during the late-Southwest Monsoon. Biogeosciences Discuss 7:25-53

Neumann Y (1913) Die pyrosomen und dolioliden der deutschen südpolar-expedition 1901-1903. In: Ergebn. Deutsche Südpol. Exped Zool 6:1-34

Perissinotto R, Mayzaud P, Nichols PD, Labat JP (2007) Grazing by Pyrosoma atlanticum (Tunicata, Thaliacea) in the south Indian Ocean. Mar Ecol Prog Ser 330:1-11

Péron F (1804) Mémoire sur le nouveau genre Pyrosoma. Ann Mus Hist Nat Paris 4(12):437-446

Rajaram LK, Krishnaswamy S (1980) A note on the similarity in the distribution of Sapphirina (Copepoda, Crustacea) and Salpa (Thaliacea, Tunicata) in the north-western Indian ocean. Mahasagar - Bull Natl Inst Oceanogr 13(1):71-77

Ramaswamy V, Sarin MM, Rengarajan R (2005) Enhanced export of carbon by salps during the northeast monsoon period in the northern Arabian Sea. Deep-Sea Res II 52:1922-1929

Rausch T (1981) The estimation of micro-algal protein content and its meaning to the evaluation of algal biomass. I Comparison of methods for extracting protein. Hydrobiologia 78:237-251

Raymont JEG, Morris RJ, Ferguson CF, Raymont JKB (1975) Variation in the amino-acid composition of lipid-free residues of marine animals from the northeast Atlantic. J Exp Mar Biol Ecol 17:261-267

Roe HSJ, Badcock J, Billett DSM, Chidgey KC, Domanski PA, Ellis CJ, Fasham MJR, Gooday AJ, Hargreaves PMD, Huggett QJ, James PT, Kirkpatrick PA, Lampitt RS, Merrett NR, Muirhead A, Pugh PR, Rice AL, Russell RA, Thurston MH, Tyle PA (1987) Great meteor east: a biological characterisation. Institute of Oceanographic Sciences Deacon Laboratory, Wormley, UK, p 322, Report No. 248

Roy R, Pratihary A, Gauns M, Naqvi SWA (2006) Spatial variation of phytoplankton pigments along the southwest coast of India. Estuar Coast Shelf Sci 69:189-195

Sawant S, Madhupratap M (1996) Seasonality and composition of phytoplankton in the Arabian Sea. Curr Sci 71:869-873

SCOR (1996) JGOFS report no. 19. Protocols for the Joint Global Ocean Flux Study (JGOFS) core measurements. Scientific Committee on Oceanic Research, International Council of Scientific Unions, Bergan, p 170

Sewell RBS (1953) The pelagic tunicata. Brit. Mus. (Nat. Hist.) John Murray Exped. 1933-34. Sci Repts 10:1-90

Takahashi K, Kuwata A, Sugisaki H, Uchikawa K, Saito H (2009) Downward carbon transport by diel vertical migration of the copepods Metridia pacifica and Metridia okhotensis in the Oyashio region of the western subarctic Pacific Ocean. Deep-Sea Res I 56:1777-1791

Thompson H (1948) Pelagic tunicates in Australia. Commonwealth Council for Scientific and Industrial Research, Melbourne, p 196

Tregouboff G, Rose M (1957) Manuel de planctonologie Mediterranéenne, vol II. Centre National de la Recherche Scientifique, Paris

UNESCO (1994) Protocols for the Joint Global Ocean Flux Study (JGOFS) core measurements. Man Guides 29:1-170

Van Heukelem (2002) HPLC phytoplankton pigments: sampling, laboratory methods, and quality assurance procedures. In: Mueller J, Fargion G (ed) Ocean optics protocols for satellite ocean color sensor validation, Revision 3, vol 2. Goddard Space Flight Center, Greenbelt, USA, pp 258-268. NASA Technical Memorandum 2002-2004

Van Soest RWM (1981) A monograph of the order Pyrosomatida (Tunicata, Thaliacea). J Plankton Res 3(4):603-631

Vaulot D, Partensky F, Neveux J, Mantoura RFC, Llewellyn C (1990) Winter presence of prochlorophytes in surface waters of the northwestern Mediterranean Sea. Limnol Oceanogr 35:1156-1164

Verity PG, Villareal TA, Smayda TJ (1988) Ecological investigations of blooms of colonial Phaeocystis pouchetii. I. Abundance, biochemical composition, and metabolic rates. J Plankton Res 10:219-248
Wiebe PH, Madin LP, Haury LR, Harbison GR, Philbin LM (1979) Diel vertical migration by Salpa aspera and its potential for large-scale particulate organic matter transport to the deep sea. Mar Biol 53:249-255

Wishner KF, Gelfman C, Gowing MM, Dawn MO, Mary R, Rebecca LW (2008) Vertical zonation and distributions of calanoid copepods through the lower oxycline of the Arabian Sea oxygen minimum zone. Prog Oceanogr 78:163-191

\section{Submit your manuscript to a SpringerOpen ${ }^{\odot}$ journal and benefit from:}

- Convenient online submission

Rigorous peer review

- Immediate publication on acceptance

- Open access: articles freely available online

- High visibility within the field

- Retaining the copyright to your article

Submit your next manuscript at $>$ springeropen.com 